\title{
Sorafenib in advanced hepatocellular carcinoma: current status and future perspectives
}

\author{
This article was published in the following Dove Press journal: \\ Journal of Hepatocellular Carcinoma \\ 12 June 2014 \\ Number of times this article has been viewed
}

\author{
Chih-Hung Hsu',4 \\ Ying-Chun Shen ${ }^{1,2}$ \\ Yu-Yun Shao ${ }^{1,4}$ \\ Chiun $\mathrm{Hsu}^{1,4}$ \\ Ann-Lii Cheng ${ }^{1,3,4}$ \\ 'Department of Oncology, \\ ${ }^{2}$ Department of Medical Research, \\ ${ }^{3}$ Department of Internal Medicine, \\ National Taiwan University Hospital, \\ ${ }^{4}$ Graduate Institute of Oncology, \\ College of Medicine, National Taiwan \\ University, Taipei, Taiwan
}

\begin{abstract}
The approval of sorafenib, a multikinase inhibitor targeting primarily Raf kinase and the vascular endothelial growth factor receptor, in 2007 for treating advanced hepatocellular carcinoma (HCC) has generated considerable enthusiasm in drug development for this difficult-to-treat disease. However, because several randomized Phase III studies testing new multikinase inhibitors failed, sorafenib remains the standard of first-line systemic therapy for patients with advanced HCC. Field practice studies worldwide have suggested that in daily practice, physicians are adopting either a preemptive dose modification or a ramp-up strategy to improve the compliance of their patients. In addition, accumulating data have suggested that patients with Child-Pugh class B liver function can tolerate sorafenib as well as patients with Child-Pugh class A liver function, although the actual benefit of sorafenib in patients with Child-Pugh class B liver function has yet to be confirmed. Whether sorafenib can be used as an adjunctive therapy to improve the outcomes of intermediate-stage HCC patients treated with transcatheter arterial chemoembolization or early-stage HCC patients after curative therapies is being investigated in several ongoing randomized Phase III studies. An increasing number of studies have reported that sorafenib exerts "off-target" effects, including the modulation of signaling pathways other than Raf/MEK/ERK pathway, nonapoptotic cell death mechanisms, and even immune modulation. Finally, although sorafenib in combination with chemotherapy or other targeted therapies has the potential to improve therapeutic efficacy in treating HCC, it also increases toxicity. Additional clinical studies are warranted to determine useful sorafenibbased combinations for the treatment of advanced HCC.
\end{abstract}

Keywords: HCC, multikinase inhibitor, advanced stage, sorafenib

\section{Introduction}

Hepatocellular carcinoma (HCC) is the fifth most common malignancy and the second leading cause of cancer-related deaths worldwide. ${ }^{1}$ Patients diagnosed in East and Southeast Asia account for more than $70 \%$ of the global burden of HCC, and the incidence of HCC in Europe and North America is also increasing. The major etiological factors of $\mathrm{HCC}$ are chronic hepatitis B virus (HBV) infection in most Asian countries, chronic hepatitis C virus (HCV) infection in Japan and Western countries, and alcoholism in Western countries. ${ }^{2,3}$ Recent studies suggest that nonalcoholic fatty liver disease, especially the aggressive form, nonalcoholic steatohepatitis, may be associated with an increased risk of HCC. ${ }^{2,4}$ Although localized HCC can be cured through resection, liver transplantation, or local ablation, only a minority of patients are eligible for these options at the time of their diagnosis., ${ }^{2,3}$ Most HCC patients eventually succumb to metastatic or locally advanced HCC.
Correspondence: Ann-Lii Cheng Department of Internal Medicine, National Taiwan University Hospital, 7 Chung-Shan South Road,

Taipei 10002, Taiwan

Tel +886223।23456 ext 6725 |

Fax +886 2 237I I I74

Email alcheng@ntu.edu.tw 
The approval of sorafenib for treating advanced HCC in 2007 represented a milestone in the history of HCC therapeutics. Sorafenib is a multikinase small-molecule inhibitor that targets several signaling pathways, especially Raf kinase and the vascular endothelial growth factor receptor (VEGFR). ${ }^{5,6}$ Two large placebo-controlled randomized Phase III trials, the Sorafenib Hepatocellular Carcinoma Assessment Randomized Protocol (SHARP) study conducted in Europe and the United States and the Sorafenib Asia-Pacific (Sorafenib-AP) study conducted in China, South Korea, and Taiwan, unequivocally underscored the survival benefit of sorafenib in patients with advanced HCC., ${ }^{7,8}$ Reduction in mortality risk was similar in both studies, and overall survival (OS) improved from 7.9 to 10.7 months in the SHARP study and from 4.2 to 6.5 months in the Sorafenib-AP study.

\section{Sorafenib remains the standard of care: 7 years on}

The success of sorafenib has generated renewed enthusiasm in exploring new drugs for HCC. However, as summarized in Table 1, none of these multikinase inhibitors or a sorafenib-based combination with another targeted agent have shown superior efficacy to sorafenib alone. ${ }^{9-12}$

Sunitinib, a multikinase inhibitor that primarily targets VEGFR and platelet-derived growth factor receptor (PDGFR), is a potent antiangiogenic agent. In an open-label, randomized Phase III study, 1,074 patients with advanced HCC were randomized to receive either sunitinib $37.5 \mathrm{mg}$ once per day or sorafenib $400 \mathrm{mg}$ twice per day. ${ }^{9}$ The median OS was significantly lower in the sunitinib arm than in the sorafenib arm (7.9 versus [vs] 10.2 months). However, a post hoc analysis revealed that the median OS in the sunitinib and sorafenib arms was similar among HBV-infected patients ( 7.6 vs 8.0 months), but was significantly different among HCV-infected patients (9.2 vs 17.6 months). In addition, sunitinib was associated with more frequent and severe adverse events (AEs).

Like sunitinib, linifanib (ABT-869) is another multikinase inhibitor that targets primarily VEGFR and PDGFR. In an open-label, randomized Phase III study, 1,035 patients with advanced HCC were randomized to receive either linifanib $17.5 \mathrm{mg}$ per day or sorafenib $400 \mathrm{mg}$ twice per day. ${ }^{10}$ Although linifanib appeared to yield a higher response rate

Table I Published Phase III studies using sorafenib as first-line systemic therapy for advanced HCC

\begin{tabular}{|c|c|c|c|c|c|c|c|}
\hline Reference & $\begin{array}{l}\text { Key eligibility } \\
\text { criteria }\end{array}$ & $\begin{array}{l}\text { Treatment } \\
\text { arm }\end{array}$ & Patient number & $\begin{array}{l}\text { Median } \\
\text { TTP } \\
\text { (months) }\end{array}$ & $\begin{array}{l}\text { HR }(95 \% \mathrm{CI}) \\
\text { in TTP }\end{array}$ & $\begin{array}{l}\text { Median OS } \\
\text { (months) }\end{array}$ & $\begin{array}{l}\text { HR }(95 \% \mathrm{Cl}) \\
\text { in OS }\end{array}$ \\
\hline \multicolumn{8}{|c|}{ Sorafenib compared with placebo } \\
\hline \multirow{2}{*}{$\begin{array}{l}\text { Llovet et al, }^{7} \\
\text { (SHARP) } 2008\end{array}$} & Pathologic diagnosis & Sorafenib vs & 299 & 5.5 & $\begin{array}{l}0.69 \\
(0.55-0.87)\end{array}$ & 10.7 & $\begin{array}{l}0.69 \\
(0.55-0.87)\end{array}$ \\
\hline & ECOG PS $=0-2$ & placebo & 303 & 2.8 & $P<0.001$ & 7.9 & $P<0.001$ \\
\hline $\begin{array}{l}\text { Cheng et al, }{ }^{8} \\
\text { (Sorafenib-AP) }\end{array}$ & $\begin{array}{l}\text { Pathologic diagnosis } \\
\text { Child-Pugh class A }\end{array}$ & Sorafenib vs & 150 & 2.8 & $\begin{array}{l}0.57 \\
(0.42-0.79)\end{array}$ & 6.5 & $\begin{array}{l}0.68 \\
(0.50-0.93)\end{array}$ \\
\hline 2009 & ECOG PS $=0-2$ & placebo & 76 & 1.4 & $P=0.0005$ & 4.2 & $P=0.014$ \\
\hline \multicolumn{8}{|c|}{ Sorafenib compared with other multikinase inhibitors } \\
\hline $\begin{array}{l}\text { Cheng et al, } \\
2013\end{array}$ & $\begin{array}{l}\text { Pathologic diagnosis } \\
\text { Child-Pugh class A }\end{array}$ & Sunitinib vs & 530 & 4.1 & $\begin{array}{l}1.13 \\
(0.98-1.31)\end{array}$ & 7.9 & $\begin{array}{l}1.30 \\
(1.13-1.50)\end{array}$ \\
\hline 2013 & ECOG PS $=0-1$ & sorafenib & 544 & 3.8 & $\begin{array}{l}P=0.8312^{*} \\
P=0.3082^{* *}\end{array}$ & 10.2 & $\begin{array}{l}P=0.990^{*} \\
P=0.0014^{* *}\end{array}$ \\
\hline $\begin{array}{l}\text { Cainap et al, }{ }^{10} \\
2013\end{array}$ & $\begin{array}{l}\text { Pathologic diagnosis } \\
\text { Child-Pugh class A }\end{array}$ & Linifanib vs & $\begin{array}{l}\mathrm{I}, 035 \\
\text { (I:I randomization) }\end{array}$ & 5.4 & $\mathrm{~N} / \mathrm{A}$ & 9.1 & $\begin{array}{l}1.046 \\
(0.896-1.221)^{\#}\end{array}$ \\
\hline 2013 & ECOG PS $=0-1$ & sorafenib & & 4.0 & & 9.8 & \\
\hline Johnson et al,"' & Pathologic diagnosis & Brivanib vs & 577 & 4.2 & 1.01 & 9.5 & $1.06^{\dagger}$ \\
\hline \multirow[t]{2}{*}{ (BRISK-FL) 2013} & Child-Pugh class A & & & & $(0.88-1.16)$ & & $(0.93-1.22)$ \\
\hline & ECOG PS $=0-1$ & sorafenib & 578 & 4.1 & $P=0.8532$ & 9.9 & $P=0.3730$ \\
\hline \multicolumn{8}{|c|}{ Sorafenib compared with sorafenib-based combination } \\
\hline \multirow[t]{2}{*}{$\begin{array}{l}\text { Zhu et al, }{ }^{12} \\
(\text { SEARCH) } 2012\end{array}$} & $\begin{array}{l}\text { Pathologic diagnosis } \\
\text { Child-Pugh class A }\end{array}$ & $\begin{array}{l}\text { Sorafenib + } \\
\text { erlotinib vs }\end{array}$ & 362 & 3.2 & $\begin{array}{l}1.135 \\
(0.944-1.366)\end{array}$ & 9.5 & $\begin{array}{l}0.929 \\
(0.78 I-1.106)\end{array}$ \\
\hline & $\mathrm{ECOG} P S=0-1$ & sorafenib & 358 & 4.0 & $P=0.91$ & 8.5 & $P=0.204$ \\
\hline
\end{tabular}

Notes: *One-sided $P$ values calculated for OS and TTP, defined in the protocol; **two-sided $P$ values; *not reaching predefined superiority or noninferiority OS boundaries; tdata derived from the per-protocol population $(n=I, I 50)$; the data was similar to OS in the intention-to-treat population $(\mathrm{HR}, \mathrm{I} .07 ; 95.8 \% \mathrm{Cl}, 0.94$ to I.23; $P=0.3 \mathrm{II}$ ). Abbreviations: $\mathrm{Cl}$, confidence interval; ECOG PS, Eastern Cooperative Oncology Group performance status; HCC, hepatocellular carcinoma; HR, hazard ratio; N/A, not available; OS, overall survival; SEARCH, Sorafenib and Erlotinib, a rAndomized tRial protoCol for the treatment of patients with Hepatocellular carcinoma; SHARP, Sorafenib Hepatocellular Carcinoma Assessment Randomized Protocol; Sorafenib-AP, Sorafenib-Asia-Pacific; TTP, time to progression. 
$(13.0 \%$ vs $6.9 \%)$ and a longer median time to tumor progression (TTP) (5.4 vs 4.0 months), no significant difference in OS between the linifanib and sorafenib arms was observed. The median OS was 9.1 months in the linifanib arm and 9.8 months in the sorafenib arm.

Brivanib is a multikinase inhibitor that targets primarily the VEGFR and fibroblast growth factor receptor (FGFR). The FGFR pathway is a key angiogenic signaling pathway that plays a critical role in the development of the drug resistance of cancer cells to VEGF-targeting therapies. ${ }^{13-15}$ In a double-blind, multinational Phase III (BRISK-FL) study, 1,155 patients with advanced $\mathrm{HCC}$ were randomized to receive either brivanib $800 \mathrm{mg}$ once per day or sorafenib $400 \mathrm{mg}$ twice per day. ${ }^{11}$ The median OS was 9.5 months in the brivanib arm and 9.9 months in the sorafenib arm. The primary endpoint of OS noninferiority among patients treated with brivanib compared with those treated with sorafenib was not met (hazard ratio $[\mathrm{HR}]=1.06 ; 95 \%$ confidence interval $[\mathrm{CI}]=0.93-1.22$ ), based on the prespecified margin (upper CI limit for $\mathrm{HR} \leq 1.08$ ). Brivanib exhibited an acceptable safety profile, but was less well-tolerated than sorafenib. Brivanib yielded higher rates of grade 3 and 4 toxicities for hypertension, fatigue, and hyponatremia, and higher rates of drug discontinuation because of AEs.

A double-blind Phase III study (SEARCH [Sorafenib and Erlotinib, a rAndomized tRial protoCol for the treatment of patients with Hepatocellular carcinoma] trial) investigated the combination of sorafenib and erlotinib, a tyrosine kinase inhibitor targeting the epidermal growth factor receptor (EGFR). ${ }^{12}$ A total of 720 patients were randomized to receive either sorafenib $400 \mathrm{mg}$ twice per day plus erlotinib $150 \mathrm{mg}$ once per day or sorafenib plus a placebo. Sorafenib plus erlotinib did not prolong either TTP (3.2 vs 4.0 months) or OS (9.5 vs 8.5 months) compared with sorafenib plus placebo. The median treatment duration was shorter (2.8 vs
4.0 months), and the withdrawal rate after one treatment cycle was greater (34.0\% vs $23.8 \%$ ) in the sorafenib plus erlotinib arm than in the sorafenib plus placebo arm.

Importantly, there might be a stage migration toward earlier patient enrollment in recently reported Phase III trials (Table 2). In the Phase III study comparing sunitinib with sorafenib, the median OS in the sorafenib arm was 8.8 months among Asian patients and 15.1 months among non-Asian patients. ${ }^{9}$ These OS times were longer than those observed in the pivotal Sorafenib-AP study (median OS, 6.5 months for Asian patients) and SHARP study (median OS, 10.7 months for non-Asian patients). Again, in the Phase III study comparing brivanib with sorafenib, the median OS in the sorafenib arm was 8.9 months among Asian patients and 11.8 months among non-Asian patients. ${ }^{11}$ The improved survival of the sorafenib arm in recent studies could be attributed to the stage migration of the patients; in other words, instead of enrolling end-stage advanced HCC patients, investigators are increasingly enrolling patients who exhibit more favorable performance statuses and less extensive diseases. Furthermore, improved skill and experience in managing the categorical toxicities of sorafenib, as well as active antiviral therapy for treating underlying hepatitis, may also play a role in improving OS. In general, the median OS in the sorafenib arm is generally around 9 months in Asian patients with advanced HCC and 12 months in Western patients. This observation must be taken into consideration for future first-line Phase III trials of systemic therapy in treating advanced HCC.

\section{Mechanisms of action: conventional and beyond}

Sorafenib, a bi-aryl urea, was initially developed as a Raf kinase inhibitor, with a potent $\mathrm{IC}_{50}$ of $6 \mathrm{nM}$ against Raf1 kinase in an in vitro kinase assay. Sorafenib also potently inhibited B-Raf kinase, proangiogenic receptor tyrosine

Table 2 Comparison of overall survival times in advanced HCC patients receiving first-line sorafenib treatment in randomized Phase III studies

\begin{tabular}{|c|c|c|c|c|c|c|}
\hline \multirow[t]{2}{*}{ Reference } & \multirow[t]{2}{*}{ Treatment } & \multirow{2}{*}{$\begin{array}{l}\text { Total patient } \\
\text { number }\end{array}$} & \multirow{2}{*}{$\begin{array}{l}\text { Asian: } \\
\text { non-Asian (\%) }\end{array}$} & \multicolumn{3}{|c|}{ Median overall survival (months) } \\
\hline & & & & $\begin{array}{l}\text { Overall } \\
\text { population }\end{array}$ & $\begin{array}{l}\text { Asian } \\
\text { subgroup }\end{array}$ & $\begin{array}{l}\text { Non-Asian } \\
\text { subgroup }\end{array}$ \\
\hline Llovet et al, 2008 & Sorafenib vs placebo & 602 & $0: 100$ & 10.7 & - & 10.7 \\
\hline Cheng et al, ${ }^{8} 2009$ & Sorafenib vs placebo & 226 & $100: 0$ & 6.5 & 6.5 & - \\
\hline Cheng et al, ${ }^{9} 2013$ & Sunitinib vs sorafenib & $\mathrm{I}, 074$ & $77: 23$ & 10.2 & 8.8 & 15.1 \\
\hline Cainap et al, ${ }^{10} 2013$ & Linifanib vs sorafenib & $\mathrm{I}, 035$ & $68: 32$ & 9.8 & N/A & N/A \\
\hline Johnson et al,"' 2013 & Brivanib vs sorafenib & $\mathrm{I}, 155$ & $62: 38$ & 9.9 & 8.9 & 11.8 \\
\hline Zhu et al, ${ }^{12} 2012$ & $\begin{array}{l}\text { Sorafenib }+ \text { erlotinib vs } \\
\text { sorafenib }\end{array}$ & 720 & N/A & 8.5 & N/A & N/A \\
\hline
\end{tabular}

Abbreviations: N/A, not available; vs, versus; HCC, hepatocellular carcinoma. 
kinases, including VEGFR1/2/3 and PDGFR $\beta$, and other receptor tyrosine kinases involved in tumorigenesis (c-Kit, Flt-3, and RET) in vitro, with $\mathrm{IC}_{50} \mathrm{~s}$ ranging from 20 to $90 \mathrm{nM} .^{5,6}$ In preclinical studies, sorafenib inhibited proliferation and induced apoptosis in cultured HCC cells, and suppressed the growth of HCC xenografts in immunocompromised mice. ${ }^{16}$ In the immunocompromised mice, growth suppression was accompanied by decrease in microvessel areas and increased tumor cell apoptosis. These data suggest that the antitumor activity of sorafenib is mediated by an indirect antiangiogenic effect on the microenvironment and a direct effect on cancer cells. ${ }^{16}$

Recent studies have explored other possible mechanisms of action through which sorafenib affects HCC. Sorafenib was found to affect multiple cell signaling pathways other than the Raf/MEK/ERK pathway, and to induce multiple mechanisms leading to apoptosis or other types of cell death in tumor cells. Furthermore, recent studies have suggested that sorafenib has "immune-modulatory" functions. Table 3 summarizes the key findings of these studies. ${ }^{16-40}$

Sorafenib, a small molecule that inhibits multiple protein kinases, can affect the intricate balance of the complex signaling network in cells. For example, inhibition of the Raf/MEK/ERK pathway can activate other prosurvival signaling pathways, such as the PI3K/AKT and transforming growth factor $\alpha /$ EGFR pathways, thus leading to sorafenib resistance. ${ }^{21,22,25}$ In preclinical studies, combinations of sorafenib and inhibitors of these compensatory prosurvival signaling pathways exhibited improved therapeutic effects. Some promising preclinical findings have been translated into clinical trials. However, the first Phase III study testing the combination of sorafenib and an EGFR inhibitor (SEARCH trial) in advanced HCC patients was unsuccessful. ${ }^{12}$

Investigating the off-target effects of sorafenib in HCC cells may lead to the discovery of new therapeutic targets. Chen et al found that downregulation of phosphorylated signal transducer and activator of transcription 3 (p-STAT3) was the key mechanism of action of sorafenib. ${ }^{17}$ This group of investigators continued to demonstrate that sorafenib targets Src homology region 2 domain-containing phosphatase 1 and increases its phosphatase activity, leading to the downregulation of p-STAT3. ${ }^{18,19}$

In addition, recent studies have suggested that sorafenib might have immune-modulatory effects. Sorafenib could affect the quantity and quality of immune cells involved in antitumor immunity, including effector $\mathrm{T}$ cells, regulatory $\mathrm{T}$ cells, natural killer cells, and tumor-associated macrophages. ${ }^{34-40}$ However, the results of these studies were not always consistent, and most of the findings have not yet been validated in patients with HCC.

Overall, the increasing number of mechanistic studies on sorafenib has enhanced our understanding of the intricate interplay between prosurvival and prodeath signaling within tumor cells as well as the complex interaction between tumor cells and host immunity within the tumor microenvironment.

\section{Prescription of sorafenib: preemptive dose modification and ramp-up}

In the pivotal SHARP and Sorafenib-AP studies, the rate of dose interruption among patients treated with sorafenib was $44 \%{ }^{7,8}$ The common toxicities leading to dose interruption were diarrhea, hand-foot skin reaction, fatigue, and skin rash/ desquamation. These data suggest that a substantial number of advanced HCC patients might not be able to tolerate the standard dose of sorafenib.

An observational study of 54 Japanese patients with Barcelona-Clinic Liver Cancer (BCLC) stage C and B diseases treated with the standard dose of sorafenib reported that $83 \%$ of the patients required at least one dose reduction, and $44 \%$ of the patients underwent the first dose reduction within the first 2 weeks of treatment. ${ }^{41}$ Another observational study of 116 patients treated with the standard dose of sorafenib in Italy reported that 62 patients $(53 \%)$ required dose reduction or temporary interruption. ${ }^{42} \mathrm{~A}$ large field practice observational study in Italy (SOFIA [SOraFenib Italian Assessment] study) enrolled 296 advanced HCC patients from six referral centers. ${ }^{43}$ Dose reduction of sorafenib was required in $54 \%$ of the patients, and treatment interruption because of treatment-related AEs was observed in $40 \%$ of the patients. Consequently, only $46 \%$ of the patients received the full dose of sorafenib over the entire treatment period, and $26 \%$ of the patients received a half dose of sorafenib for more than $70 \%$ of the treatment period. Patients who received a half dose of sorafenib for more than $70 \%$ of treatment period had significantly longer treatment duration (median 6.8 vs 3 months) and significantly longer OS (median 21.6 vs 9.6 months) than other patients. ${ }^{43}$ These studies suggested that dose modification and/or dose interruption are common in HCC patients treated with the standard dose of sorafenib. The results of the SOFIA study implied that timely dose modification may lead to an increased treatment duration and an improved patient outcome.

The "preemptive dose modification" strategy, in which dose modification is implemented earlier than recommended 
Table 3 Published studies exploring mechanisms of action of sorafenib in HCC

\begin{tabular}{|c|c|}
\hline Reference & Key finding \\
\hline \multicolumn{2}{|c|}{ On cellular signaling pathways } \\
\hline $\begin{array}{l}\text { Chen et al, }{ }^{17} 2010 \\
\text { and Tai et al, }{ }^{18} 201 \mathrm{I}\end{array}$ & Downregulation of p-STAT3 \\
\hline Ou et al, ${ }^{20} 2010$ & Activation of JNK \\
\hline Gedaly et al, ${ }^{21} 2010$ & Activation of PI3K/AKT pathway \\
\hline $\begin{array}{l}\text { Lanchemayer } \\
\text { et al, }{ }^{23} 2012\end{array}$ & $\begin{array}{l}\text { Downregulation of WNT } \\
\text { signaling and } \beta \text {-catenin protein }\end{array}$ \\
\hline
\end{tabular}

Liu et al, ${ }^{24} 2012$

Inhibition of hypoxia-induced HIF-I $\alpha$ protein expression

Zhao et al, ${ }^{25} 2014$

Activation of TGF $\alpha / E G F R$ pathway

On cell death mechanisms

Liu et al, ${ }^{16} 2006$

Downregulation of Mcl-I

Ou et al, ${ }^{27} 2009$

Increasing Bim protein expression

Chiou et al, ${ }^{28} 2009$

Increasing production of ROS

Ou et $\mathrm{al}^{20} 2010$

Galmiche et al, ${ }^{30}$

2010

Shi et al, ${ }^{31} 2011$

Li et al, ${ }^{32} 2012$

Downregulation of c-IAPI

Sonntag et al, ${ }^{33}$

Increasing expression of PUMA

2014

On immune cell function and immune microenvironment Cao et al, ${ }^{34} 201 \mathrm{l}$

Decreasing the suppressive immune cell populations (Treg and MDSC)

Cabrera et al, ${ }^{35}$ 2013

Immune modulation on effector CD4 and Treg function

$\begin{array}{ll}\text { Wang et al, }{ }^{36} 2013 & \begin{array}{l}\text { Decreasing tumor-infiltrated } \\ \text { Treg cells }\end{array} \\ \text { Zhang et al, }{ }^{37} 2013 & \begin{array}{l}\text { Reducing the number and } \\ \text { function of NK cells }\end{array}\end{array}$

Sprinzl et al, ${ }^{38} 2013 \quad$ Triggering activation of hepatic NK cells
Mechanistic insight or translational implication

Sorafenib inhibited HCC via a kinase-independent mechanism; downregulation of P-STAT3 was mediated by upregulating SHP-I (a phosphatase) activity. ${ }^{17,18}$

Activation of JNK, which contributes to induction of GADD45 $\beta$, preferentially occurred in sorafenib-sensitive HCC cells. Sorafenibinduced JNK activation was independent of Raf/MEK/ERK.

Combination of sorafenib and a dual PI3K/mTOR inhibitor produced a synergistic antitumor effect against $\mathrm{HCC}$ in vitro and in vivo. ${ }^{21,22}$

Two different Wnt-related molecular classes (CTNNBI and Wnt-TGF $\beta$ ) were identified, accounting for half of all HCC patients. Sorafenib could modulate $\beta$-catenin/Wnt signaling in experimental models that harbor the CTNNBI class signature.

This downregulation of HIF-I $\alpha$ was associated with downregulation of mTOR/p70S6K/4E-BPI and ERK. Sorafenib also decreased VEGF protein expression.

Hypoxic HC cells contributed to the activation of TGF $\alpha / E G F R$ pathway, upregulation of HIF- $2 \alpha$, and resistance to sorafenib.

An ERK-independent mechanism contributed to increased apoptosis in $\mathrm{HCC}$ cells. In another study, the combination of sorafenib and ABT-737, which could inactivate $\mathrm{Bcl}-\mathrm{xL}$, led to strong suppression of $\mathrm{HCC}$ cells. ${ }^{26}$

Bim activation mediated the synergistic antitumor effect of sorafenib and MEK inhibitor in HCC cells.

A mitochondria-dependent oxidative stress mechanism mediated the apoptosis induced by sorafenib in HepG2 cells. In another study, serum levels of advanced oxidative protein products were increased in HCC patients treated with sorafenib. ${ }^{29}$

Induction of GADD45 $\beta$, through activation of JNK, contributed to the sorafenib-induced apoptosis in $\mathrm{HCC}$ cells.

Sorafenib, via an ERK-independent manner, increased BAD expression and prevented its inhibitory phosphorylation in HCC cells.

Sorafenib, via an MEK/ERK-independent manner, induced apoptosis and autophagy. The ER stress-induced cell death was attenuated by autophagy activation. Inhibition of autophagy enhanced sorafenib-induced cell death. Sorafenib decreased the protein expression level of c-IAPI by targeting the internal ribosome entry site within the c-IAPI mRNA.

Sorafenib-mediated apoptosis in murine hepatoma cells, not in syngeneic mouse primary hepatocytes, was associated with the expression of PUMA.

Treg and MDSC were increased in the spleens and bone marrows of the $B A L B / c$ mice with liver hepatoma. Sorafenib treatment inhibited HCC cell growth in mice, and significantly decreased the suppressive immune cell populations.

In T cells cultured from patients with HCC, subpharmacologic doses of sorafenib $(<3 \mu \mathrm{M})$ increased effector $\mathrm{T}$ cell activation while blocking Treg function, and pharmacologic doses of sorafenib (6 12 $\mu \mathrm{M})$ decreased effector $T$ cell activation.

In tumor infiltrated mononuclear cells from 19 HCC patients, tumorinfiltrated regulatory $T$ cells were decreased significantly and TGF- $\beta$ signal pathways were downregulated after sorafenib.

In a mouse model, suppression of NK cells by sorafenib contributed to prometastatic effects in HCC. The study suggests immunotherapeutic approaches activating NK cells may enhance the efficacy of sorafenib in HCC patients.

In a mouse model, sorafenib triggered proinflammatory activity of tumorassociated macrophages and induced antitumor NK cell responses in a cytokine- and NF-KB-dependent fashion. 
Table 3 (Continued)

\begin{tabular}{lll}
\hline Reference & Key finding & Mechanistic insight or translational implication \\
\hline Chen et al, ${ }^{39} 2014$ & $\begin{array}{l}\text { Enhancing functions of tumor- } \\
\text { specific effector T cells }\end{array}$ & $\begin{array}{l}\text { In a mouse model, sorafenib enhanced functions of effector T cells, and } \\
\text { decreased the number and functions of PD-I-expressing CD8+ T cells } \\
\text { and Tregs in a tumor microenvironment. } \\
\text { In a mouse model, sorafenib intensified tumor hypoxia, which then } \\
\text { infiltration }\end{array}$ \\
& $\begin{array}{l}\text { Increased SDFI } \alpha \text { expression, Gr-I+ myeloid cell infiltration, and } \\
\text { in } 2014\end{array}$ & $\begin{array}{l}\text { subsequently tumor fibrosis. Combination of CXCR4 inhibitor or } \\
\text { depletion of Gr-I+ cells improved the therapeutic efficacy of sorafenib. }\end{array}$ \\
\hline
\end{tabular}

Abbreviations: 4E-BPI, eukaryotic translation initiation factor 4E-binding protein I; BAD, Bcl-2-associated death promoter; Bcl-xL, B-cell lymphoma-extra large; CXCR4, C-X-C chemokine receptor type 4; IAP, the inhibitors of apoptosis; EGFR, epidermal growth factor receptor; ER, endoplasmic reticulum; ERK, extracellular signal-regulated kinase; GADD45 $\beta$, growth arrest DNA damage induced gene 45 $\beta$; HCC, hepatocellular carcinoma; HIF, hypoxia-inducing factor; JNK, c-Jun NH2-terminal kinase; MDSC, myeloid-derived suppressor cell; MEK, mitogen-activated protein kinase kinase; mTOR, mammalian target of rapamycin; NK cells, natural killer cells; NF-KB, nuclear factor kappa-light-chain-enhancer of activated B cells; P-STAT3, phosphorylated signal transducer and activator of transcription 3; PI3K, phosphatidylinositol-4,5bisphosphate 3-kinase; PUMA, p53 upregulated modulator of apoptosis; ROS, reactive oxidative species; SDFI $\alpha$, stromal-derived factor I $\alpha$; SHP-I, Src homology region 2 domain-containing phosphatase- I; TGF, transforming growth factor; Treg, regulatory T cell; WNT, wingless-related integration site.

in the package insert, has become common practice. The dose modification rule for sorafenib as listed in the package insert requests treatment interruption upon grade $\geqq 2$ dermatological toxicities, grade $\geqq 3$ hematological toxicities, or grade $\geqq 4$ other nonhematological toxicities; the treatment can be resumed with dose modification when the toxicities recover to grade 0 or $1 .^{7,8}$ This dosing guideline often leads to an overshooting of toxicities and treatment interruption. Furthermore, it has been shown that interruption of antiangiogenic therapy may induce a "rebound" phenomenon; that is, rapid tumor growth upon drug withdrawal. ${ }^{44}$ Therefore, it is reasonable that physicians tend to follow up with their patients frequently and reduce the dose of sorafenib preemptively to prevent overshooting of toxicities and treatment interruption.

Alternatively, a "ramp-up" strategy, which involves administering sorafenib to high-risk patients at a reduced dose initially and escalating the dose only when the toxicity is acceptable, ${ }^{45}$ has also become popular in clinical practice. The GIDEON (Global Investigation of therapeutic DEcisions in hepatocellular carcinoma and Of its treatment with sorafeNib) study was conducted to evaluate the safety of sorafenib in real-world practice. ${ }^{46}$ Of the 1,571 patients eligible for safety analysis, $22 \%$ were treated with an initial dose of $400 \mathrm{mg}$ per day. In a single-institute-based retrospective study conducted in Japan, 38 of 96 (40\%) HCC patients were treated with sorafenib at the initial dose of $400 \mathrm{mg}$ per day. ${ }^{47}$ In a community-based study conducted in Canada, 66 of $99(66 \%)$ HCC patients were treated with sorafenib at the initial dose of $400 \mathrm{mg}$ per day. ${ }^{48}$

Overall, these observational studies have indicated that sorafenib prescription, either starting with a reduced dose (ie, "ramp-up" strategy) or earlier dose modification, is associated with improved patient compliance ${ }^{45,48}$ and noninferior or improved OS. ${ }^{43,45,47-49}$

\section{Indications for sorafenib: later and earlier}

According to the pivotal SHARP and Sorafenib-AP studies, sorafenib is indicated for advanced-stage HCC patients with good liver function reserves (ie, Child-Pugh class A). Whether sorafenib also plays a role in patients with impaired liver function (ie, Child-Pugh class B) (Table 4) as well as in earlier stages, including BCLC stage A and stage B, is being explored.

\section{Advanced HCC with impaired liver function reserve}

In the first Phase II clinical trial of sorafenib in advanced HCC, reported by Abou-Alfa et al, 38 (28\%) of the 136 patients enrolled had Child-Pugh B liver function reserve. ${ }^{50,51}$ The median treatment duration of sorafenib for Child-Pugh class B patients was 1.8 months, and their median OS was 3.2 months. The incidences of sorafenibrelated AEs, including hand-foot skin reaction, fatigue, and diarrhea, were similar in Child-Pugh class B and Child-Pugh class A patients. However, grade 3 or 4 hyperbilirubinemia, ascites, and encephalopathy were more frequently observed in Child-Pugh class B patients than in class A patients. These liver-related AEs were likely the consequence of deterioration of the underlying hepatic condition in Child-Pugh class B patients. No significant difference in the pharmacokinetic profiles of sorafenib, including the area under the curve and peak concentration values, was observed between ChildPugh class B patients and Child-Pugh class A patients. ${ }^{51}$

In the study reported by Pressiani et al, 63 (21\%) patients with advanced $\mathrm{HCC}$ were classified as Child-Pugh class B. ${ }^{52,53}$ The median treatment duration of sorafenib and the median OS for Child-Pugh class B patients were 1.9 months and 3.8 months, respectively. ${ }^{52}$ The median daily doses did not differ significantly between patients with Child-Pugh class A 
and class B liver function (744 and $762 \mathrm{mg}$ ). The type and frequency of AEs were similar in the two patient groups; however, grade 3 or 4 cachexia and liver failure were more frequently observed in Child-Pugh class B patients than in class A patients. ${ }^{52}$

Of the 120 consecutive HCC patients treated with sorafenib at a single institute in France, 18 patients with Child-Pugh class B liver function were, in a 1:3 ratio, matched to patients with Child-Pugh class A liver function in terms of age, performance status, tumor numbers and sizes, portal vein thrombosis, and serum alpha-fetoprotein levels. ${ }^{54}$ No significant difference in the mean dose intensity of sorafenib was noted between Child-Pugh class B and Child-Pugh class A patients. The frequencies of all-grade and grade 3 or 4 drug-induced AEs were similar in the two patient groups. Child-Pugh class B patients tended to have a shorter median duration of treatment (2.3 vs 4.3 months) and a poorer OS (4.5 vs 10 months) than did class $\mathrm{A}$ patients. $^{54}$

In the second interim analysis of the GIDEON study, 367 of the 1,571 patients were classified as Child-Pugh class B. ${ }^{46}$ The median duration of sorafenib treatment was approximately 2.0 months. ${ }^{46}$ The median daily doses (680 mg vs $721 \mathrm{mg}$ ) of sorafenib, drug-related all-grade AEs (67\% vs 63\%), and drug-related grade 3 or 4 AEs ( $24 \%$ vs $22 \%$ ) were similar in Child-Pugh class A and class B patients. The rate of drug-related AEs, calculated as event per patient-year, was similar in Child-Pugh class A and class B patients. However, the number of drug-related serious AEs was slightly higher in Child-Pugh class B patients than in class A patients (15\% vs $8 \%$ ).

The aforementioned studies and other small-scale studies summarized in Table $4^{43,46,49-52,54-60}$ have consistently shown that sorafenib can be safely administered to patients with Child-Pugh class B liver function. Most studies have indicated that sorafenib-related AEs do not significantly differ between Child-Pugh class B and class A patients. However, the OS of Child-Pugh class B patients treated with sorafenib remains short (median 3-4 months). The actual survival benefit of sorafenib in Child-Pugh class B patients remains unknown.

\section{Sorafenib for earlier-stage HCC}

Because sorafenib suppresses angiogenesis and tumor cell proliferation, the two crucial factors mediating tumor recurrence and progression, it is anticipated that sorafenib may improve the outcomes of HCC following locoregional therapies.
Combining sorafenib and transcatheter arterial chemoembolization (TACE) to treat intermediate-stage (or BCLC stage B) $\mathrm{HCC}$ has been investigated in multiple single-arm studies (Table 5). ${ }^{61-65}$ In general, the combinations were safe and potentially helpful. The only published Phase III trial, conducted in Japan and Korea, randomized 458 intermediate-stage HCC patients exhibiting $\geq 25 \%$ tumor necrosis or shrinkage after one or two sessions of TACE into the sorafenib or placebo arm. The primary endpoint was TTP by central review. The results revealed that TTP was not significantly improved in the sorafenib arm (median, 5.4 vs 3.7 months). ${ }^{66}$ The median time from last TACE to randomization was 9.3 weeks, and the median daily dose of sorafenib was only $386 \mathrm{mg} .{ }^{66}$ The relatively long lag in beginning sorafenib treatment after TACE and the low daily sorafenib dose might have contributed to the negative results of the study. The SPACE trial was a placebo-controlled randomized Phase II study that evaluated the efficacy and safety of sorafenib in combination with TACE using doxorubicin-eluting beads for treating intermediate-stage HCC.$^{67}$ A total of 307 patients were randomized to receive sorafenib or a placebo continually; all patients received first TACE 3-7 days after the first dose of the studied drugs, and subsequent TACE on defined time points at months 3,7 , and 13, and every 6 months thereafter. The primary endpoint was TTP determined according to independent review. The TTP did not differ significantly between the sorafenib and placebo arms (median, 169 vs 167 days). ${ }^{67}$ Several Phase III randomized, placebo-controlled trials evaluating the efficacy of sorafenib in combination with TACE are ongoing. ${ }^{68,69}$

Tumor recurrence develops in more than $70 \%$ of $\mathrm{HCC}$ patients receiving curative-intent local therapy. Except for possibly effective antiviral agents for carriers of $\mathrm{HBV}$ or $\mathrm{HCV}$, there is no currently approved agent exhibiting efficacy in preventing or delaying tumor recurrence in $\mathrm{HCC}$ patients who have received curative treatment. ${ }^{70}$ The efficacy of sorafenib as an adjuvant therapy for HCC after curative therapy has been explored in the placebo-controlled, randomized Phase III STORM (Sorafenib as adjuvant Treatment in the Prevention Of Recurrence of Hepatocellular CarcinoMa) study. In the trial, 1,100 HCC patients who had underwent curative treatment (surgical resection or local ablation) were randomized to receive either sorafenib $400 \mathrm{mg}$ twice daily or a placebo for 4 years or until disease recurrence. The primary endpoint was recurrence-free survival. However, in a recent press announcement, the study did not meet its primary endpoint. ${ }^{71}$ 
Table 4 Studies evaluating outcomes of Child-Pugh class A and class B patients treated with sorafenib for advanced HCC

\begin{tabular}{|c|c|c|c|c|c|c|}
\hline Reference & $\begin{array}{l}\text { Child-Pugh } \\
\text { class }\end{array}$ & $\begin{array}{l}\text { Patient } \\
\text { number }\end{array}$ & $\begin{array}{l}\text { Median treatment } \\
\text { duration (months) }\end{array}$ & $\begin{array}{l}\text { Median TTP } \\
\text { (months) }\end{array}$ & $\begin{array}{l}\text { Median OS } \\
\text { (months) }\end{array}$ & $\begin{array}{l}\text { Key findings about Child-Pugh } \\
\text { class B patients treated with } \\
\text { sorafenib }\end{array}$ \\
\hline \multicolumn{7}{|l|}{ Clinical trial } \\
\hline Abou-Alfa et al, ${ }^{50,51}$ & $A$ & 98 & 4.0 & 5.0 & 9.5 & \multirow{2}{*}{$\begin{array}{l}\text { More likely to have worsening } \\
\text { cirrhosis; poorer outcome than } \\
\text { Child-Pugh A patients }\end{array}$} \\
\hline 2006 & B & 38 & 1.8 & 3.0 & 3.2 & \\
\hline Pressiani et al, ${ }^{52}$ & A & 234 & 4.2 & 4.2 & 10.0 & \multirow{2}{*}{$\begin{array}{l}\text { Can tolerate and may benefit } \\
\text { from sorafenib treatment }\end{array}$} \\
\hline 2013 & B & 63 & 1.9 & 3.8 & 3.8 & \\
\hline \multicolumn{7}{|c|}{ Prospective observational study } \\
\hline Hollebecque et al, ${ }^{54}$ & A & $100(54)^{\dagger}$ & N/A (4.3) & N/A (3.6) & $13.0(10)$ & \multirow{2}{*}{$\begin{array}{l}\text { Similar and acceptable sorafenib } \\
\text { toxicity profile, but poor survival } \\
\text { due to liver dysfunction }\end{array}$} \\
\hline 2011 & B & $20(18)$ & N/A (2.3) & N/A (2.5) & $4.5(4.5)$ & \\
\hline Lencioni et al ${ }^{46}$ & A & 957 & $3.2^{\#}$ & N/A & N/A & \multirow{3}{*}{$\begin{array}{l}\text { Sorafenib safety profile is similar } \\
\text { irrespective of Child-Pugh status }\end{array}$} \\
\hline \multirow[t]{2}{*}{$($ GIDEON)* 2014} & B & 367 & $2.0^{\#}$ & $\mathrm{~N} / \mathrm{A}$ & $\mathrm{N} / \mathrm{A}$ & \\
\hline & C & 35 & $0.9^{\#}$ & $\mathrm{~N} / \mathrm{A}$ & $\mathrm{N} / \mathrm{A}$ & \\
\hline lavarone et $\mathrm{al}^{43}$ & $A$ & 259 & 4.2 & 10 & 12.7 & \\
\hline (SOFIA) 2011 & B & 37 & 2.0 & 6.9 & 7.7 & \\
\hline Wörns MA et al, ${ }^{55}$ & $A$ & 15 & 2.8 & $\mathrm{~N} / \mathrm{A}$ & 7.2 & \multirow{3}{*}{$\begin{array}{l}\text { More likely to have worsening liver } \\
\text { dysfunction or failure; should be } \\
\text { treated with caution }\end{array}$} \\
\hline \multirow[t]{2}{*}{2009} & B & 15 & 1.8 & $\mathrm{~N} / \mathrm{A}$ & 3.3 & \\
\hline & C & 4 & 2.9 & $\mathrm{~N} / \mathrm{A}$ & 3.4 & \\
\hline \multicolumn{7}{|c|}{ Retrospective study } \\
\hline Pinter $M$ et al, ${ }^{56}$ & A & 26 & $\mathrm{~N} / \mathrm{A}$ & 2.2 & 8.3 & \multirow{3}{*}{$\begin{array}{l}\text { Higher incidence of severe AE } \\
\text { (including Gl bleeding) }\end{array}$} \\
\hline \multirow[t]{2}{*}{2009} & B & 23 & $\mathrm{~N} / \mathrm{A}$ & 2.9 & 4.3 & \\
\hline & C & 10 & $\mathrm{~N} / \mathrm{A}$ & $\mathrm{N} / \mathrm{A}$ & 1.5 & \\
\hline Ozenne et al, ${ }^{57}$ & A & 33 & 5.0 & $\mathrm{~N} / \mathrm{A}$ & 8.9 & \multirow{2}{*}{$\begin{array}{l}\text { Survival was very short. Opportunity } \\
\text { of treatment for Child-Pugh B } \\
\text { patients is questionable }\end{array}$} \\
\hline 2010 & B & 17 & 1.8 & N/A & 2.0 & \\
\hline Wörns MA et al, ${ }^{58}$ & $A$ & 60 & 4.0 & $\mathrm{~N} / \mathrm{A}$ & 10.5 & Presence of MVI was a poor \\
\hline \multirow[t]{2}{*}{2013} & B & 42 & 3.0 & $N / A$ & 6.0 & \multirow{4}{*}{$\begin{array}{l}\text { prognostic factor; while presence of } \\
\text { ascites was not a prognostic factor } \\
\text { Shorter OS for Child-Pugh B patients }\end{array}$} \\
\hline & C & 8 & 2.3 & $\mathrm{~N} / \mathrm{A}$ & 3.0 & \\
\hline \multirow[t]{2}{*}{ Kudo et al, ${ }^{49} 2012$} & $A$ & 149 & $\mathrm{~N} / \mathrm{A}$ & $\mathrm{N} / \mathrm{A}$ & 16.3 & \\
\hline & B & 39 & $N / A$ & $\mathrm{~N} / \mathrm{A}$ & 9.3 & \\
\hline Kim HY et al, ${ }^{59}$ & A (score $=5)$ & 134 & $\mathrm{~N} / \mathrm{A}$ & $\mathrm{N} / \mathrm{A}$ & 8.4 & \multirow{4}{*}{$\begin{array}{l}\text { Child-Pugh score was important in } \\
\text { predicting outcomes; presence of } \\
\text { ascites was significant prognostic factor } \\
\text { in Child-Pugh B (score 7) patients }\end{array}$} \\
\hline \multirow[t]{3}{*}{2013} & A $($ score $=6)$ & 111 & N/A & $\mathrm{N} / \mathrm{A}$ & 5.1 & \\
\hline & B (score $=7)$ & 51 & N/A & $\mathrm{N} / \mathrm{A}$ & 3.4 & \\
\hline & $\mathrm{B}($ score $=8,9)$ & 29 & $N / A$ & $\mathrm{~N} / \mathrm{A}$ & 2.6 & \\
\hline Køstner $\mathrm{AH}$ et $\mathrm{al}^{60}$ & A & 43 & 3.2 & $N / A$ & 6.6 & \multirow{2}{*}{$\begin{array}{l}\text { Child-Pugh B patients had poor OS; } \\
\text { routine use of sorafenib for these } \\
\text { patients could not be recommended }\end{array}$} \\
\hline 2013 & $B$ and $C$ & 29 and 4 & 1.5 & $N / A$ & 3.6 & \\
\hline
\end{tabular}

Notes: *Second interim analysis results; ${ }^{*}$ data were originally reported in months; values reported here were approximates; ${ }^{\dagger}$ data presented in parentheses are those of the case-control study based on 18 Child-Pugh class B patients with I:3 ratio matched Child-Pugh class A patients.

Abbreviations: AE, adverse event; GI, gastrointestinal; GIDEON, Global Investigation of therapeutic DEcisions in hepatocellular carcinoma and Of its treatment with sorafeNib; HCC, hepatocellular carcinoma; MVI, macrovascular invasion; N/A, not available; OS, overall survival; SOFIA, SOraFenib Italian Assessment; TTP, time to progression.

\section{Sorafenib-based combinations: a promising must}

In the pivotal SHARP and Sorafenib-AP studies, the objective tumor response rates were only $2 \%$ to $3 \%{ }^{7,8}$ Combination strategies with the objective of improving the efficacy of sorafenib have been explored extensively (Table 6).

Abou-Alfa et al conducted a randomized Phase II study comparing sorafenib plus doxorubicin versus doxorubicin plus a placebo in patients with advanced HCC. ${ }^{72}$ The median TTPs were 6.4 months (95\% CI, 4.8-9.2 months) for patients who received doxorubicin plus sorafenib, and 2.8 months $(95 \%$ CI, 1.6-5 months) for those who received doxorubicin plus the placebo. The median OS was significantly longer in patients receiving the combination ( 13.7 vs 6.5 months) than in patients who received doxorubicin plus the placebo. However, the combination of sorafenib with doxorubicin resulted in substantially increased toxicities. A Phase III study comparing sorafenib plus doxorubicin with sorafenib alone is ongoing.

To avoid the excessive toxicity related to doxorubicin, several other chemotherapeutic agents have been tested in 


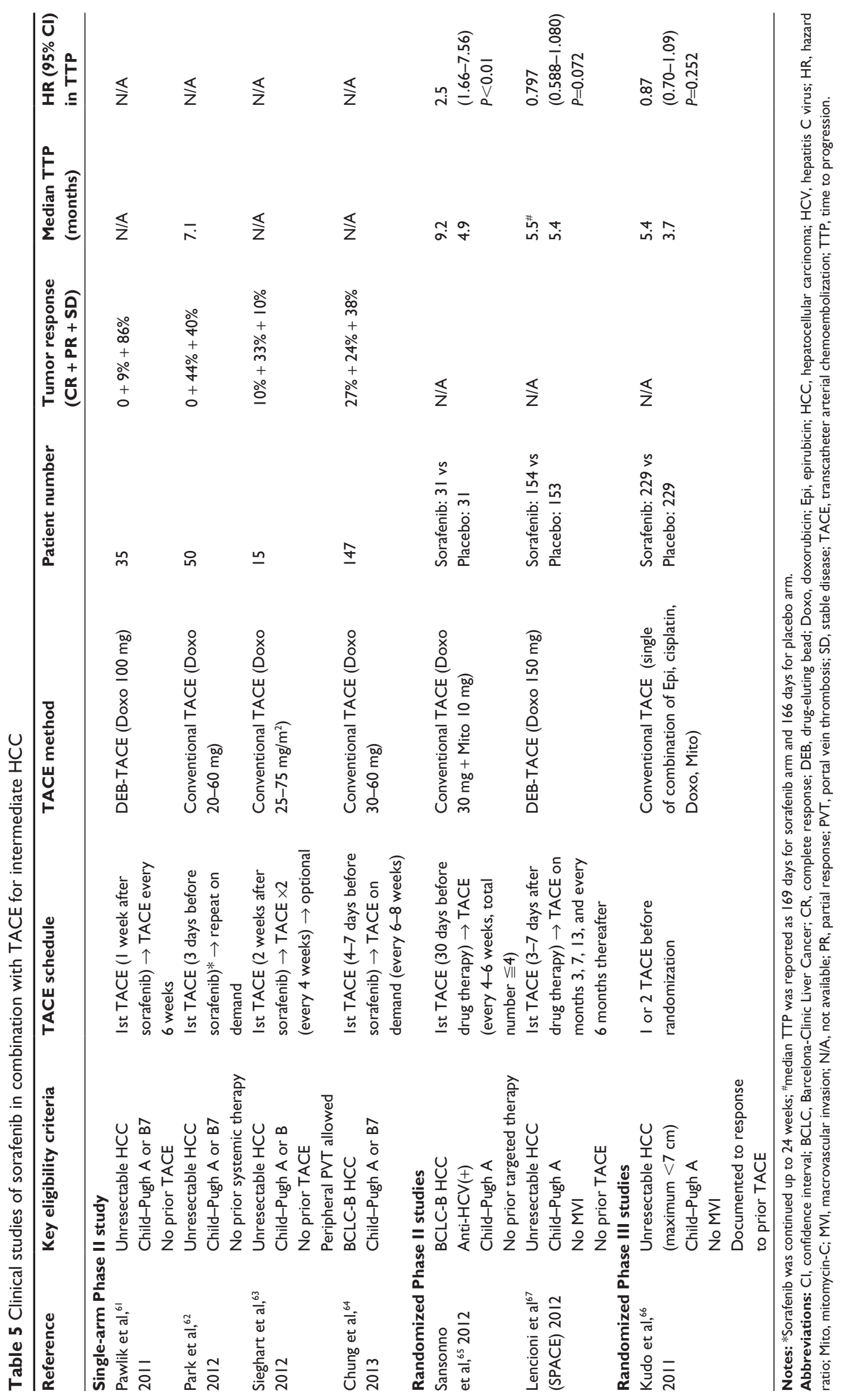









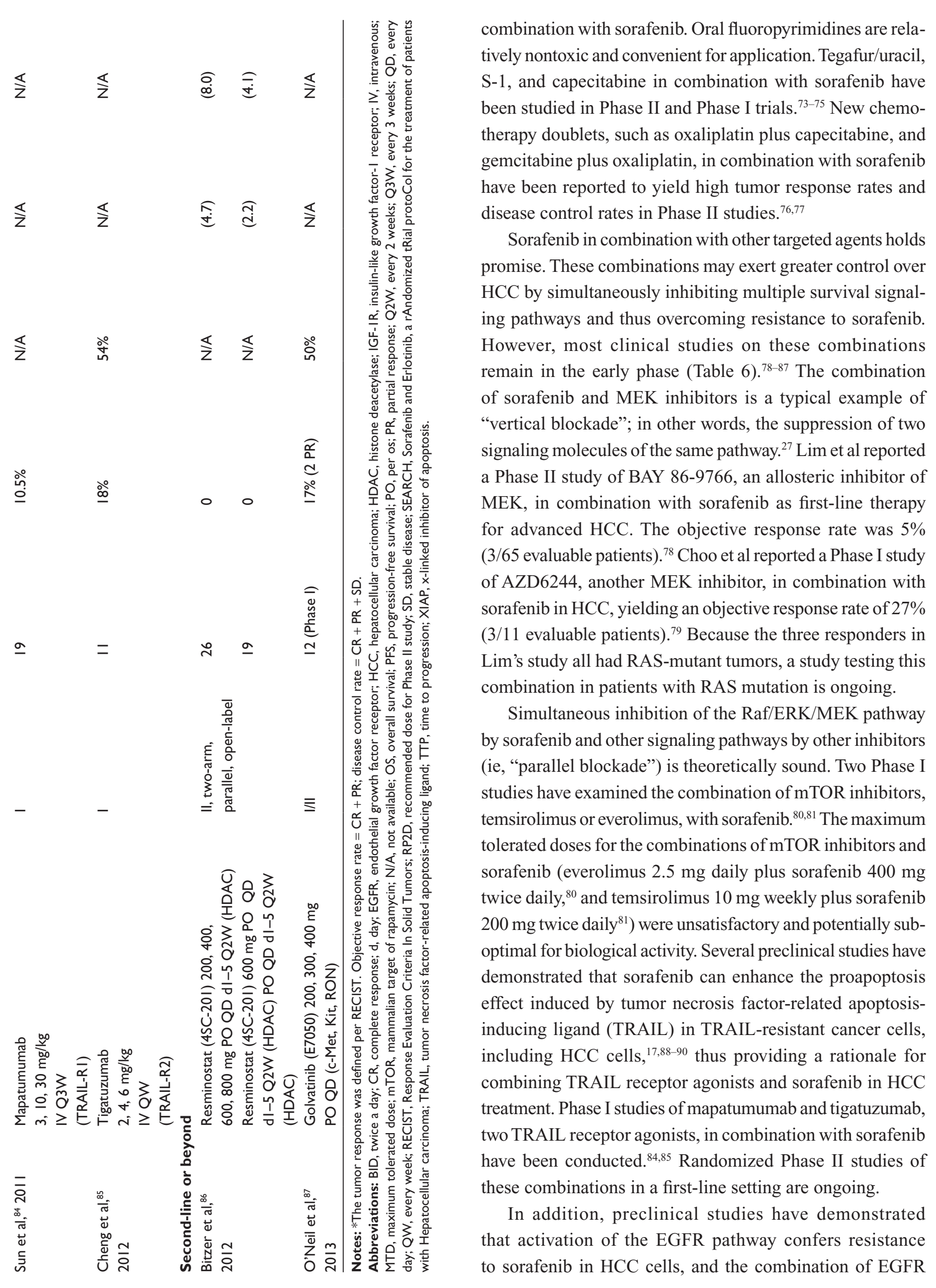


inhibitors and sorafenib improved the antitumor effect of sorafenib in experimental HCC models. ${ }^{25,91,92}$ However, the results of the Phase III randomized placebo-controlled double-blind study testing the combination of sorafenib and erlotinib did not show survival benefit. ${ }^{12}$

\section{Conclusion and future perspectives}

Despite numerous clinical and preclinical studies, sorafenib remains the only drug approved for advanced HCC. Recently published clinical trials have indicated that the median OS of the sorafenib arm is now approximately 9 months for Asians and 12 months for non-Asians., ${ }^{9,11}$ Preemptive dose modification and the ramp-up strategy of sorafenib prescription have gradually been adopted in daily practice to improve patients' compliance and avoid treatment interruption.

Sorafenib can safely be administered to Child-Pugh class B patients, although the survival advantage remains unclear. Large randomized trials examining the benefits of sorafenib as an adjunctive therapy for intermediate-stage HCC patients receiving locoregional therapies such as TACE, and as an adjuvant therapy for early-stage HCC patients who have undergone curative therapy are ongoing.

Because the clinical benefit of sorafenib is relatively modest, biomarkers predictive of the efficacy of sorafenib must be identified to avoid imposing needless toxicities upon patients who do not benefit from the treatment. ${ }^{93}$ Furthermore, in-depth mechanistic studies on sorafenib as well as the proper design and execution of clinical trials are critical for future success. Finally, as our understanding of the landscape of genetic alterations in HCC rapidly improves, ${ }^{94-99}$ personalized targeted therapy, with or without sorafenib, will become possible.

\section{Acknowledgment}

This study was supported by a grant from National Science Council, Taiwan (100CAP1020-2).

\section{Disclosure}

Ann-Lii Cheng was a consultant of Daiichi Sankyo, Merck Serono, Eisai, Jennerex, and Exelixis, and received research funding from Sanofi-Aventis, Chugai, and MSD. The other authors report no conflicts of interest in this work.

\section{References}

1. International Agency for Cancer Research. GLOBOCAN 2008 [webpage on the Internet]. http://globocan.iarc.fr. Accessed October 4, 2013.

2. El-Serag HB. Hepatocellular carcinoma. $N$ Engl J Med. 2011;365(12): $1118-1127$

3. Forner A, Llovet JM, Bruix J. Hepatocellular carcinoma. Lancet. 2012;379(9822):1245-1255.
4. Starley BQ, Calcagno CJ, Harrison SA. Nonalcoholic fatty liver disease and hepatocellular carcinoma: a weighty connection. Hepatology. 2010;51(5):1820-1832.

5. Wilhelm SM, Carter C, Tang L, et al. BAY 43-9006 exhibits broad spectrum oral antitumor activity and targets the RAF/MEK/ERK pathway and receptor tyrosine kinases involved in tumor progression and angiogenesis. Cancer Res. 2004;64(19):7099-7109.

6. Wilhelm S, Carter C, Lynch M, et al. Discovery and development of sorafenib: a multikinase inhibitor for treating cancer. Nat Rev Drug Discov. 2006;5(10):835-844.

7. Llovet JM, Ricci S, Mazzaferro V, et al; SHARP Investigators Study Group. Sorafenib in advanced hepatocellular carcinoma. N Engl J Med. 2008:359(4):378-390.

8. Cheng AL, Kang YK, Chen Z, et al. Efficacy and safety of sorafenib in patients in the Asia-Pacific region with advanced hepatocellular carcinoma: a phase III randomised, double-blind, placebo-controlled trial. Lancet Oncol. 2009;10(1):25-34.

9. Cheng AL, Kang YK, Lin DY, et al. Sunitinib versus sorafenib in advanced hepatocellular cancer: results of a randomized phase III trial. J Clin Oncol. 2013;31(32):4067-4075.

10. Cainap C, Qin S, Huang WT, et al. Phase III trial of linifanib versus sorafenib in patients with advanced hepatocellular carcinoma (HCC). J Clin Oncol. 2013;31(Suppl 4):Abs 249.

11. Johnson PJ, Qin S, Park JW, et al. Brivanib versus sorafenib as firstline therapy in patients with unresectable, advanced hepatocellular carcinoma: results from the randomized phase III BRISK-FL study. J Clin Oncol. 2013;31(28):3517-3524.

12. Zhu AX, Rosmorduc O, Evans J, et al. SEARCH: a phase III, randomized, double-blind, placebo-controlled trial of sorafenib plus erlotinib in patients with hepatocellular carcinoma (HCC). ESMO Congress. 2012;Abs 917.

13. Cheng AL, Shen YC, Zhu AX. Targeting fibroblast growth factor receptor signaling in hepatocellular carcinoma. Oncology. 2011;81(5-6):372-380.

14. Casanovas O, Hicklin DJ, Bergers G, Hanahan D. Drug resistance by evasion of antiangiogenic targeting of VEGF signaling in late-stage pancreatic islet tumors. Cancer Cell. 2005;8(4):299-309.

15. Bergers G, Hanahan D. Modes of resistance to anti-angiogenic therapy. Nat Rev Cancer. 2008;8(8):592-603.

16. Liu L, Cao Y, Chen C, et al. Sorafenib blocks the RAF/MEK/ ERK pathway, inhibits tumor angiogenesis, and induces tumor cell apoptosis in hepatocellular carcinoma model PLC/PRF/5. Cancer Res. 2006;66(24):11851-11858.

17. Chen KF, Tai WT, Liu TH, et al. Sorafenib overcomes TRAIL resistance of hepatocellular carcinoma cells through the inhibition of STAT3. Clin Cancer Res. 2010;16(21):5189-5199.

18. Tai WT, Cheng AL, Shiau CW, et al. Signal transducer and activator of transcription 3 is a major kinase-independent target of sorafenib in hepatocellular carcinoma. J Hepatol. 2011;55(5):1041-1048.

19. Tai WT, Shiau CW, Chen PJ, et al. Discovery of novel Src homology region 2 domain-containing phosphatase 1 agonists from sorafenib for the treatment of hepatocellular carcinoma. Hepatology. 2014;59(1):190-201.

20. Ou DL, Shen YC, Yu SL, et al. Induction of DNA damage-inducible gene GADD45beta contributes to sorafenib-induced apoptosis in hepatocellular carcinoma cells. Cancer Res. 2010;70(22): 9309-9318.

21. Gedaly R, Angulo P, Hundley J, et al. PI-103 and sorafenib inhibit hepatocellular carcinoma cell proliferation by blocking Ras/ Raf/MAPK and PI3K/AKT/mTOR pathways. Anticancer Res. 2010;30(12):4951-4958.

22. Gedaly R, Angulo P, Chen C, et al. The role of PI3K/mTOR inhibition in combination with sorafenib in hepatocellular carcinoma treatment. Anticancer Res. 2012;32(7):2531-2536.

23. Lachenmayer A, Alsinet C, Savic R, et al. Wnt-pathway activation in two molecular classes of hepatocellular carcinoma and experimental modulation by sorafenib. Clin Cancer Res. 2012;18(18):4997-5007. 
24. Liu LP, Ho RL, Chen GG, Lai PB. Sorafenib inhibits hypoxia-inducible factor- $1 \alpha$ synthesis: implications for antiangiogenic activity in hepatocellular carcinoma. Clin Cancer Res. 2012;18(20):5662-5671.

25. Zhao D, Zhai B, He C, et al. Upregulation of HIF-2 $\alpha$ induced by sorafenib contributes to the resistance by activating the TGF- $\alpha /$ EGFR pathway in hepatocellular carcinoma cells. Cell Signal. 2014;26(5): 1030-1039.

26. Hikita H, Takehara T, Shimizu S, et al. The Bcl-xL inhibitor, ABT737, efficiently induces apoptosis and suppresses growth of hepatoma cells in combination with sorafenib. Hepatology. 2010;52(4): 1310-1321.

27. Ou DL, Shen YC, Liang JD, et al. Induction of Bim expression contributes to the antitumor synergy between sorafenib and mitogenactivated protein kinase/extracellular signal-regulated kinase kinase inhibitor CI-1040 in hepatocellular carcinoma. Clin Cancer Res. 2009;15(18):5820-5828.

28. Chiou JF, Tai CJ, Wang YH, Liu TZ, Jen YM, Shiau CY. Sorafenib induces preferential apoptotic killing of a drug- and radio-resistant Hep G2 cells through a mitochondria-dependent oxidative stress mechanism. Cancer Biol Ther. 2009;8(20):1904-1913.

29. Coriat R, Nicco C, Chéreau C, et al. Sorafenib-induced hepatocellular carcinoma cell death depends on reactive oxygen species production in vitro and in vivo. Mol Cancer Ther. 2012;11(10):2284-2293.

30. Galmiche A, Ezzoukhry Z, François C, et al. BAD, a proapoptotic member of the BCL2 family, is a potential therapeutic target in hepatocellular carcinoma. Mol Cancer Res. 2010;8(8):1116-1125.

31. Shi YH, Ding ZB, Zhou J, et al. Targeting autophagy enhances sorafenib lethality for hepatocellular carcinoma via ER stress-related apoptosis. Autophagy. 2011;7(10):1159-1172.

32. Li XF, Gong RY, Wang M, et al. Sorafenib down-regulates c-IAP expression post-transcriptionally in hepatic carcinoma cells to suppress apoptosis. Biochem Biophys Res Commun. 2012;418(3):531-536.

33. Sonntag R, Gassler N, Bangen JM, Trautwein C, Liedtke C. Proapoptotic Sorafenib signaling in murine hepatocytes depends on malignancy and is associated with PUMA expression in vitro and in vivo. Cell Death Dis. 2014;5:e1030.

34. Cao M, Xu Y, Youn JI, et al. Kinase inhibitor Sorafenib modulates immunosuppressive cell populations in a murine liver cancer model Lab Invest. 2011;91(4):598-608

35. Cabrera R, Ararat M, Xu Y, et al. Immune modulation of effector $\mathrm{CD} 4+$ and regulatory $\mathrm{T}$ cell function by sorafenib in patients with hepatocellular carcinoma. Cancer Immunol Immunother. 2013;62(4): 737-746.

36. Wang Q, Yu T, Yuan Y, et al. Sorafenib reduces hepatic infiltrated regulatory $\mathrm{T}$ cells in hepatocellular carcinoma patients by suppressing TGF-beta signal. J Surg Oncol. 2013;107(4):422-427.

37. Zhang QB, Sun HC, Zhang KZ, et al. Suppression of natural killer cells by sorafenib contributes to prometastatic effects in hepatocellular carcinoma. PLoS One. 2013;8(2):e55945.

38. Sprinzl MF, Reisinger F, Puschnik A, et al. Sorafenib perpetuates cellular anticancer effector functions by modulating the crosstalk between macrophages and natural killer cells. Hepatology. 2013;57(6): 2358-2368.

39. Chen ML, Yan BS, Lu WC, et al. Sorafenib relieves cell-intrinsic and cell-extrinsic inhibitions of effector T cells in tumor microenvironment to augment antitumor immunity. Int J Cancer. 2014;134(2):319-331.

40. Chen Y, Huang Y, Reiberger T, et al. Differential effects of sorafenib on liver versus tumor fibrosis mediated by stromal-derived factor 1 alpha/C-X-C receptor type 4 axis and myeloid differentiation antigenpositive myeloid cell infiltration in mice. Hepatology. 2014;59(4): 1435-1447.

41. Ogasawara S, Kanai F, Obi S, et al. Safety and tolerance of sorafenib in Japanese patients with advanced hepatocellular carcinoma. Hepatol Int. 2011;5(3):850-856.

42. Di Costanzo GG, Tortora R, Iodice L, et al. Safety and effectiveness of sorafenib in patients with hepatocellular carcinoma in clinical practice. Dig Liver Dis. 2012;44(9):788-792.
43. Iavarone M, Cabibbo G, Piscaglia F, et al; SOFIA (SOraFenib Italian Assessment) study group. Field-practice study of sorafenib therapy for hepatocellular carcinoma: a prospective multicenter study in Italy. Hepatology. 2011;54(6):2055-2063.

44. Ebos JM, Lee CR, Cruz-Munoz W, Bjarnason GA, Christensen JG, Kerbel RS. Accelerated metastasis after short-term treatment with a potent inhibitor of tumor angiogenesis. Cancer Cell. 2009;15(3): 232-239.

45. Sacco R, Bargellini I, Ginanni B, et al. Long-term results of sorafenib in advanced-stage hepatocellular carcinoma: what can we learn from routine clinical practice? Expert Rev Anticancer Ther. 2012;12(7):869-875.

46. Lencioni R, Kudo M, Ye SL, et al. GIDEON (Global Investigation of therapeutic DEcisions in hepatocellular carcinoma and Of its treatment with sorafeNib): second interim analysis. Int J Clin Pract. 2014;68(5):609-617.

47. Nakano M, Tanaka M, Kuromatsu R, et al. Efficacy, safety, and survival factors for sorafenib treatment in Japanese patients with advanced hepatocellular carcinoma. Oncology. 2013;84(2):108-114.

48. Shingina A, Hashim AM, Haque M, et al. In a 'real-world', clinicbased community setting, sorafenib dose of $400 \mathrm{mg} /$ day is as effective as standard dose of $800 \mathrm{mg} /$ day in patients with advanced hepatocellular carcimona, with better tolerance and similar survival. Can $J$ Gastroenterol. 2013;27(7):393-396.

49. Kudo M, Ueshima K, Arizumi T. Real-life clinical practice with sorafenib in advanced hepatocellular carcinoma: a single-center experience. Dig Dis. 2012;30(6):609-616.

50. Abou-Alfa GK, Schwartz L, Ricci S, et al. Phase II study of sorafenib in patients with advanced hepatocellular carcinoma. J Clin Oncol. 2006;24(26):4293-4300.

51. Abou-Alfa GK, Amadori D, Santoro A, et al. Safety and efficacy of sorafenib in patients with Hepatocellular Carcinoma (HCC) and ChildPugh A versus B cirrhosis. Gastrointest Cancer Res. 2011;4(2):40-44.

52. Pressiani T, Boni C, Rimassa L, et al. Sorafenib in patients with Child-Pugh class A and B advanced hepatocellular carcinoma: a prospective feasibility analysis. Ann Oncol. 2013;24(2):406-411.

53. Rimassa L, Pressiani T, Boni C, et al. A phase II randomized dose escalation trial of sorafenib in patients with advanced hepatocellular carcinoma. Oncologist. 2013;18(4):379-380.

54. Hollebecque A, Cattan S, Romano O, et al. Safety and efficacy of sorafenib in hepatocellular carcinoma: the impact of the Child-Pugh score. Aliment Pharmacol Ther. 2011;34(10):1193-1201.

55. Wörns MA, Weinmann A, Pfingst K, et al. Safety and efficacy of sorafenib in patients with advanced hepatocellular carcinoma in consideration of concomitant stage of liver cirrhosis. J Clin Gastroenterol. 2009;43(5):489-495.

56. Pinter M, Sieghart W, Graziadei I, et al. Sorafenib in unresectable hepatocellular carcinoma from mild to advanced stage liver cirrhosis. Oncologist. 2009;14(1):70-76.

57. Ozenne V, Paradis V, Pernot S, et al. Tolerance and outcome of patients with unresectable hepatocellular carcinoma treated with sorafenib. Eur J Gastroenterol Hepatol. 2010;22(9):1106-1110.

58. Wörns MA, Koch S, Niederle IM, et al. The impact of patient and tumour baseline characteristics on the overall survival of patients with advanced hepatocellular carcinoma treated with sorafenib. Dig Liver Dis. 2013;45(5):408-413.

59. Kim HY, Park JW, Joo J, et al. Worse outcome of sorafenib therapy associated with ascites and Child-Pugh score in advanced hepatocellular carcinoma. J Gastroenterol Hepatol. 2013;28(11):1756-1761.

60. Køstner AH, Sorensen M, Olesen RK, Grønbæk H, Lassen U, Ladekarl M. Sorafenib in advanced hepatocellular carcinoma: a nationwide retrospective study of efficacy and tolerability. Scientific World Journal. 2013;2013:931972.

61. Pawlik TM, Reyes DK, Cosgrove D, Kamel IR, Bhagat N, Geschwind JF. Phase II trial of sorafenib combined with concurrent transarterial chemoembolization with drug-eluting beads for hepatocellular carcinoma. J Clin Oncol. 2011;29(30):3960-3967. 
62. Park JW, Koh YH, Kim HB, et al. Phase II study of concurrent transarterial chemoembolization and sorafenib in patients with unresectable hepatocellular carcinoma. J Hepatol. 2012;56(6):1336-1342.

63. Sieghart W, Pinter M, Reisegger M, et al. Conventional transarterial chemoembolisation in combination with sorafenib for patients with hepatocellular carcinoma: a pilot study. Eur Radiol. 2012;22(6): $1214-1223$.

64. Chung YH, Han G, Yoon JH, et al. Interim analysis of START: Study in Asia of the combination of TACE (transcatheter arterial chemoembolization) with sorafenib in patients with hepatocellular carcinoma trial. Int J Cancer. 2013;132(10):2448-2458.

65. Sansonno D, Lauletta G, Russi S, Conteduca V, Sansonno L, Dammacco F. Transarterial chemoembolization plus sorafenib: a sequential therapeutic scheme for HCV-related intermediate-stage hepatocellular carcinoma: a randomized clinical trial. Oncologist. 2012;17(3):359-366.

66. Kudo M, Imanaka K, Chida N, et al. Phase III study of sorafenib after transarterial chemoembolisation in Japanese and Korean patients with unresectable hepatocellular carcinoma. Eur J Cancer. 2011;47(14): 2117-2127.

67. Lencioni R, Llovet JM, Han G, et al. Sorafenib or placebo in combination with transarterial chemoembolization (TACE) with doxorubicin-eluting beads (DEBDOX) for intermediate-stage hepatocellular carcinoma (HCC): phase II, randomized, double-blind SPACE trial. J Clin Oncol. 2012;30(Suppl 4):Abs LBA154.

68. Hsu C, Po-Ching-Liang, Morita S, Hu FC, Cheng AL. Perspectives on the design of clinical trials combining transarterial chemoembolization and molecular targeted therapy. Liver Cancer. 2012;1(3-4): $168-176$.

69. Shen YC, Lin ZZ, Hsu CH, Hsu C, Shao YY, Cheng AL. Clinical trials in hepatocellular carcinoma: an update. Liver Cancer. 2013;2(3-4): $345-364$.

70. Villanueva A, Hernandez-Gea V, Llovet JM. Medical therapies for hepatocellular carcinoma: a critical view of the evidence. Nat Rev Gastroenterol Hepatol. 2013;10(1):34-42.

71. News Room on March 11, 2014. Bayer and Onyx report Phase 3 study results of NEXAVAR ${ }^{\circledR}$ (sorafenib) as adjuvant treatment for patients with liver cancer who have undergone surgery or local ablation [webpage on the Internet]. Available from: http://pharma.bayer. com/html/pdf/STORM_Release_FINAL.pdf. Assessed March 12, 2014.

72. Abou-Alfa GK, Johnson P, Knox JJ, et al. Doxorubicin plus sorafenib vs doxorubicin alone in patients with advanced hepatocellular carcinoma: a randomized trial. JAMA. 2010;304(19):2154-2160.

73. Hsu CH, Shen YC, Lin ZZ, et al. Phase II study of combining sorafenib with metronomic tegafur/uracil for advanced hepatocellular carcinoma. J Hepatol. 2010;53(1):126-131.

74. Lee SJ, Lee J, Park SH, et al. Phase 1 trial of S-1 in combination with sorafenib for patients with advanced hepatocellular carcinoma. Invest New Drugs. 2012;30(4):1540-1547.

75. Rojas-Hernandez CM, PattYZ, Fekrazad MH, Steinberg KA, Roach M, Lee FC. Phase II trial of sorafenib (S) and capecitabine (C) for hepatocellular carcinoma (HCC) in cirrhotic patients (pts). J Clin Oncol.2013;31(Suppl 15):Abs e15131.

76. Assenat E, Boige V, Thézenas $S$, et al. Sorafenib (S) alone versus $S$ combined with gemcitabine and oxaliplatin (GEMOX) in first-line treatment of advanced hepatocellular carcinoma (HCC): Final analysis of the randomized phase II GONEXT trial (UNICANCER/FFCD PRODIGE 10 trial). J Clin Oncol. 2013;31(Suppl 15):Abs 4028.

77. Yau TC, Cheung FY, Lee F, et al. A multicenter phase II study of sorafenib, capecitabine, and oxaliplatin (SECOX) in patients with advanced hepatocellular carcinoma: Final results of Hong KongSingapore Hepatocellular Carcinoma Research Collaborative Group study. J Clin Oncol. 2013;31(Suppl 15):Abs 4117.

78. Lim HY, Yen CJ, Tak WY, et al. A phase II trial of MEK inhibitor BAY 86-9766 in combination with sorafenib as first-line systemic treatment for patients with unresectable hepatocellular carcinoma (HCC). J Clin Oncol. 2012;30 (Suppl 15):Abs 4103.
79. Choo SP, Ng QS, Chen WJJ, et al. A phase I/II study of AZD6244 in combination with sorafenib in advanced hepatocellular carcinoma. J Clin Oncol. 2012;30(Suppl 15):Abs 4100.

80. Finn RS, Poon RT, Yau T, et al. Phase I study investigating everolimus combined with sorafenib in patients with advanced hepatocellular carcinoma. J Hepatol. 2013;59(6):1271-1277.

81. Kelley RK, Nimeiri HS, Munster PN, et al. Temsirolimus combined with sorafenib in hepatocellular carcinoma: a phase I dose-finding trial with pharmacokinetic and biomarker correlates. Ann Oncol. 2013;24(7):1900-1907.

82. Faivre SJ, Fartoux L, Bouattour M, et al. A phase I study of AVE1642, a human monoclonal antibody-blocking insulin-like growth factor-1 receptor (IGF-1R), given as a single agent and in combination with sorafenib as first-line therapy in patients with advanced hepatocellular carcinoma (HCC). J Clin Oncol. 2011;29(Suppl 4):Abs 270.

83. Lee AS, Zee BC, Cheung FY, et al. Randomized phase II study of the $\mathrm{x}$-linked inhibitor of apoptosis (XIAP) antisense AEG35156 in combination with sorafenib in patients with advanced hepatocellular carcinoma (HCC). J Clin Oncol. 2012;30(Suppl 15):Abs 4105.

84. Sun W, Nelson D, Alberts SR, et al. Phase Ib study of mapatumumab in combination with sorafenib in patients with advanced hepatocellular carcinoma (HCC) and chronic viral hepatitis. J Clin Oncol. 2011; 29(Suppl 4):Abs 261.

85. Cheng AL, Kang YK, Byoo BY, et al. Phase Ib dose-escalation study of a phase II randomized trial to assess the safety and tolerability of tigatuzumab (CS-1008) in combination with sorafenib in patients (pts) with advanced hepatocellular carcinoma (HCC). J Clin Oncol. 2012; 30(Suppl 15):Abs e14617.

86. Bitzer M, Giannini EG, Horger M, et al. Efficacy, tolerability and pharmacokinetics of the oral histone deacetylase inhibitor resminostat in patients with advanced hepatocellular carcinoma: clinical data from the phase II SHELTER study. ILCA Annual Conference 2012:Abs $\mathrm{O}-030$.

87. O'Neil BH, Bendell JC, Modiano MR, et al. Phase I/II study of E7050 (golvantinib) in combination with sorafenib in patients (pts) with advanced hepatocellular carcinoma (HCC): Phase I results. $J$ Clin Oncol. 2013;31(Suppl 4):Abs 294.

88. Meng XW, Lee SH, Dai H, et al. Mcl-1 as a buffer for proapoptotic Bcl-2 family members during TRAIL-induced apoptosis: a mechanistic basis for sorafenib (Bay 43-9006)-induced TRAIL sensitization. J Biol Chem. 2007;282(41):29831-29846.

89. Rosato RR, Almenara JA, Coe S, Grant S. The multikinase inhibitor sorafenib potentiates TRAIL lethality in human leukemia cells in association with Mcl-1 and cFLIPL down-regulation. Cancer Res. 2007;67(19):9490-9500.

90. Ricci MS, Kim SH, Ogi K, et al. Reduction of TRAIL-induced Mcl-1 and cIAP2 by c-Myc or sorafenib sensitizes resistant human cancer cells to TRAIL-induced death. Cancer Cell. 2007;12(1):66-80.

91. Ezzoukhry Z, Louandre C, Trécherel E, et al. EGFR activation is a potential determinant of primary resistance of hepatocellular carcinoma cells to sorafenib. Int $J$ Cancer. 2012;131(12):2961-2969.

92. Blivet-Van Eggelpoël MJ, Chettouh H, Fartoux L, et al. Epidermal growth factor receptor and HER-3 restrict cell response to sorafenib in hepatocellular carcinoma cells. J Hepatol. 2012;57(1):108-115.

93. Shao YY, Hsu CH, Cheng AL. Predictive biomarkers of antiangiogenic therapy for advanced hepatocellular carcinoma: where are we? Liver Cancer. 2013;2(2):93-107.

94. Li M, Zhao H, Zhang X, et al. Inactivating mutations of the chromatin remodeling gene ARID2 in hepatocellular carcinoma. Nat Genet. 2011;43(9):828-829.

95. Guichard C, Amaddeo G, Imbeaud S, et al. Integrated analysis of somatic mutations and focal copy-number changes identifies key genes and pathways in hepatocellular carcinoma. Nat Genet. 2012;44(6): 694-698.

96. Fujimoto A, Totoki Y, Abe T, et al. Whole-genome sequencing of liver cancers identifies etiological influences on mutation patterns and recurrent mutations in chromatin regulators. Nat Genet. 2012;44(7): $760-764$. 
97. Huang J, Deng Q, Wang Q, et al. Exome sequencing of hepatitis B virus-associated hepatocellular carcinoma. Nat Genet. 2012;44(10): $1117-1121$.

98. Kan Z, Zheng H, Liu X, et al. Whole-genome sequencing identifies recurrent mutations in hepatocellular carcinoma. Genome Res. 2013;23(9):1422-1433.
99. Cleary SP, Jeck WR, Zhao X, et al. Identification of driver genes in hepatocellular carcinoma by exome sequencing. Hepatology. 2013;58(5):1693-1702.

\section{Publish your work in this journal}

The Journal of Hepatocellular Carcinoma is an international, peerreviewed, open access journal that offers a platform for the dissemination and study of clinical, translational and basic research findings in this rapidly developing field. Development in areas including, but not limited to, epidemiology, vaccination, hepatitis therapy, pathology and molecular tumor classification and prognostication are all considered for publication. The manuscript management system is completely online and includes a very quick and fair peer-review system, which is all easy to use. Visit http://www.dovepress.com/testimonials.php to read real quotes from published authors.

\footnotetext{
Submit your manuscript here: http://www.dovepress.com/journal-of-hepatocellular-carcinoma-journal
} 